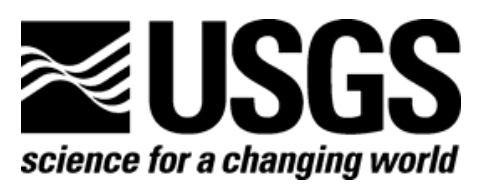

Hawaiian Volcano Observatory

\title{
Lava Flow Hazard Assessment, as of August 2007, for Kīlauea East Rift Zone Eruptions, Hawai‘i Island
}

By Jim Kauahikaua

Report Series 2007-1264 


\section{U.S. Department of the Interior DIRK KEMPTHORNE, Secretary}

\section{U.S. Geological Survey \\ Mark D. Myers, Director}

U.S. Geological Survey, Reston, Virginia 2007

For product and ordering information:

World Wide Web: http://www.usgs.gov/pubprod

Telephone: 1-888-ASK-USGS

For more information on the USGS - the Federal source for science about the Earth, its natural and living resources, natural hazards, and the environment:

World Wide Web: http://www.usgs.gov

Telephone: 1-888-ASK-USGS

Suggested citation:

Kauahikaua, Jim, 2007, Lava flow hazard assessment, as of August 2007, for Kīlauea East Rift Zone eruptions, Hawai'i Island: U.S. Geological Survey Open-File Report 2007-1264, 9 p.

Any use of trade, product, or firm names is for descriptive purposes only and does not imply endorsement by the U.S. Government.

Although this report is in the public domain, permission must be secured from the individual copyright owners to reproduce any copyrighted material contained within this report. 


\section{Contents}

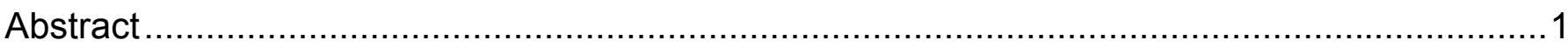

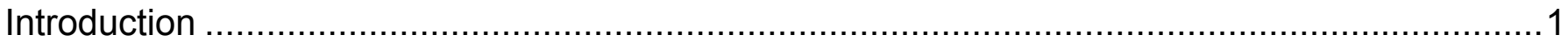

Lava Flow Hazards posed by Kīlauea Volcano in the Puna District....................................... 1

Lava Flow Hazard Zones are a qualitative estimate of inundation frequency .........................2

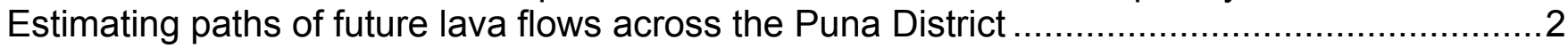

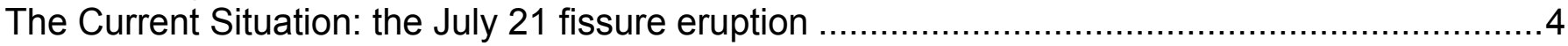

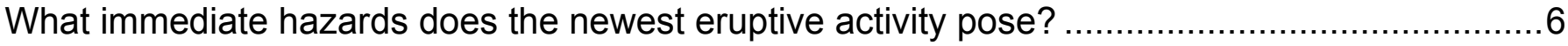

What future hazards does the newest eruptive activity pose? ............................................

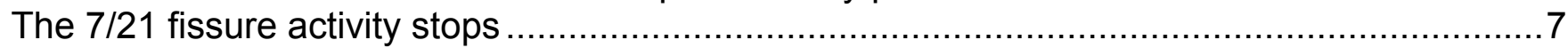

The $7 / 21$ fissure activity continues to feed a channel that spawn 'a'ā lava flows ......................

The $7 / 21$ fissure channel crusts over and spawns pāhoehoe lava flows and tubes .................. 7

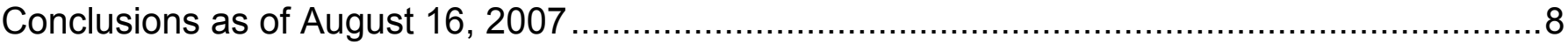

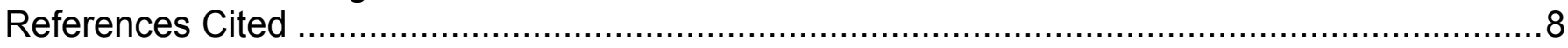

\section{Figures}

1. Map for part of the Puna District. Shown in red are lava flows from the $7 / 21$ fissure eruption. Pink lines show paths of steepest descent. Yellow, Pu'u 'Ō'ō - Kupaianaha flow field (19832007); green, Hawai'i Volcanoes National Park not covered by Pu'u 'Ō'ō - Kupaianaha lava flows.

2. Calculated flow paths superimposed on geologic map of Island of Hawai'i.

3. Lava flow map as of August 26, 2007. Black lines and arrowheads show the tracks of four 'a'ā flows that started from the fissure $D$ channel. Gray represents primarily 'a'ā lava flows emplaced during the fountaining episodes of Pu'u 'Ō'o (1983-1986); green represents forested areas not inundated by lava flows since 1977; yellow represents primarily pāhoehoe lava flows emplaced from 1986 to 1992 .

4. Looking back toward Pu'u 'Ō'ō, a perched lava pond was forming over fissure D in this July 23, 2007 photo. Pu'u Kahauale'a is the vegetated cone behind the perched pond... 


\title{
Lava Flow Hazard Assessment, as of August 2007, for Kīlauea East Rift Zone Eruptions, Hawai'i Island
}

\author{
By Jim Kauahikaua'
}

\begin{abstract}
The most recent episode in the ongoing $\mathrm{Pu}^{\prime} \mathrm{u}{ }^{\prime} \overline{\mathrm{O}}^{‘} \overline{\mathrm{o}}-$ Kupaianaha eruption of Kîlauea Volcano is currently producing lava flows north of the east rift zone. Although they pose no immediate threat to communities, changes in flow behavior could conceivably cause future flows to advance downrift and impact communities thus far unaffected. This report reviews lava flow hazards in the Puna District and discusses the potential hazards posed by the recent change in activity. Members of the public are advised to increase their general awareness of these hazards and stay up-to-date on current conditions.
\end{abstract}

\section{Introduction}

The ongoing $\mathrm{Pu}^{‘} \mathrm{u}$ ' $\overline{\mathrm{O}}^{`} \overline{\mathrm{o}}-$ Kupaianaha eruption of Kîlauea Volcano has been producing lava flows for more than 24 years. The vast majority of those flows advanced to the southeast, destroying nearly 200 structures and covering $117 \mathrm{~km}^{2}$ (almost 29,000 acres). On July 21, 2007, a fissure opened immediately east of $\mathrm{Pu}^{`} \mathrm{u}{ }^{`} \overline{\mathrm{O}}^{`} \overline{\mathrm{o}}$ and, initially, sent short flows to both the north and south sides of the rift zone from lava ponds perched over the fissures. The south-trending flows stagnated as eruptive activity became increasingly localized at the easternmost end of the fissure. Over the next few weeks, a lava flow fed from the east end of the fissure advanced $6 \mathrm{~km}$ to the northeast, stalled, and produced additional flows advancing along the northern edge of the previous flow (fig. $1)$.

The change in vent location, focus of lava flows to the northeast, and the potential longevity of the eruption warrants a hazard assessment that specifically addresses the current eruptive situation and discusses plausible outcomes. As of August 26, 2007, lava flows posed no immediate threats to any communities.

\section{Lava flow hazards by Kīlauea Volcano in the Puna District}

The Puna District has been inundated by lava flows from both the summit and east rift zone of Kilauea Volcano in the last several hundred years. The east rift zone has been active frequently, with at least 15 eruptions in Puna since 1900. Most of these eruptions have produced lava flows that either stayed within the rift zone or flowed south or southeast toward the coast. In 1840, a lava

\footnotetext{
${ }^{1}$ Hawaiian Volcano Observatory, Hawai‘i Volcanoes National Park, HI 96718
} 
flow advanced through what is now Nānāwale Estates and entered the ocean immediately east of Hawaiian Beaches subdivision. Much of the Puna District north of the east rift zone was last inundated by lava during a 60 -year eruption in the $15^{\text {th }}$ century (Clague and others, 1999).

\section{Lava flow hazard zones are a qualitative estimate of inundation frequency}

The USGS Hawai' $i$ Island Lava Flow Hazard Zone (LFHZ) map (Wright and others, 1992) is a qualitative assessment of the hazards for the island. The Puna District includes hazard zones 1,2, and 3. Zone 1 includes actual and possible vent areas. Zone 2 consists of "areas adjacent to and downslope of active rift zones." Zone 3 includes "areas gradationally less hazardous than Zone 2 because of greater distance from recently active vents and/or because the topography makes it less likely that flows will cover these areas." All areas can expect inundation by lava flows in the long term with higher-numbered zones being inundated less frequently than the lower-numbered zones.

The most recent east rift zone activity is the $\mathrm{Pu}^{‘} \mathrm{u}{ }^{\prime}{ }^{`}{ }^{‘} \overline{\mathrm{o}}-$ Kupaianaha eruption that started in 1983 and has inundated areas within LFHZ 1, 2, and 3. The July 21 fissure is within LFHZ 1 and the lava flows are, so far, progressing along the boundary between zone 1 and 3 . The area south of the east rift zone is in LFHZ 2; the area north of zone 1 near $\mathrm{Pu}^{\prime} \mathrm{u}{ }^{~}{ }^{\prime}{ }^{‘} \bar{o}$ and the July 21 fissure is in zone 3.

\section{Estimating paths of future lava flows across the Puna District}

For current and future eruptions, lava flow paths may be estimated by calculating the path of steepest descent using an appropriate digital elevation model (DEM) of the Puna District. Tools calculating "paths of steepest descent" are commonplace in many Geographic Information System (GIS) software packages. The topography is first represented by a numerical grid; the topography of the Puna District was represented by a square grid in which each element measures $30 \mathrm{~m}$ by 30 $\mathrm{m}$. IDRISI GIS routines then calculate how a gravitationally driven flow would move from each element in the grid to every other element. A second grid is produced in which each cell contains an integer representing the number of grid elements that flow into each cell. The actual flow paths can then be extracted by selecting only the grid elements that receive flow from a minimum number of other elements. For example, figure 1 shows a map of the grid elements that receive flow from more than 1,000 upslope grid elements in the Puna District. A representation of this calculation was included in the Hawai'i State Lava Flow Hazard Mitigation Plan (Hawai'i State Civil Defense, 2002). 


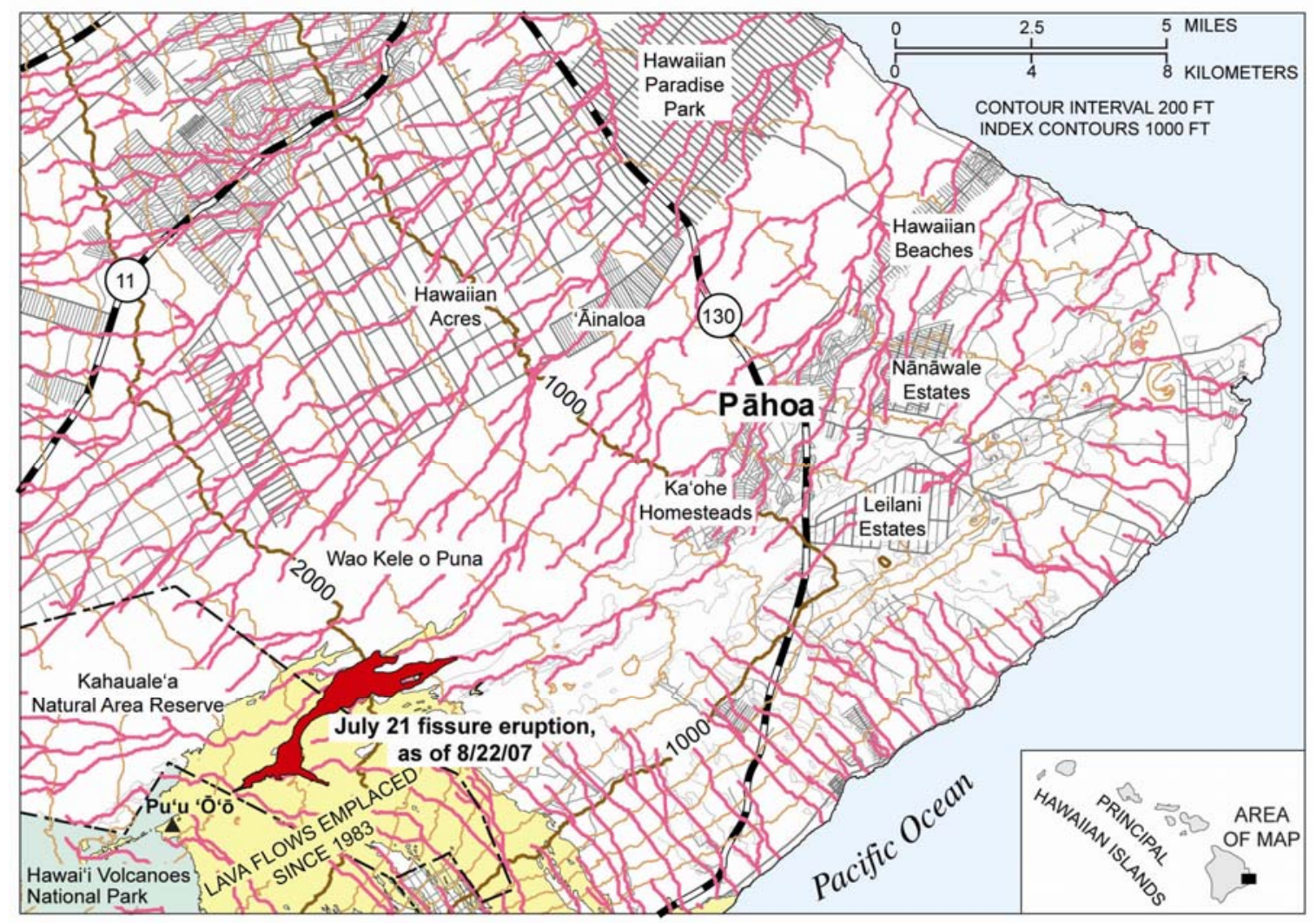

Figure 1. Map for part of the Puna District. Shown in red are lava flows from the 7/21 fissure eruption. Pink lines show paths of steepest descent. Yellow, $\mathrm{Pu}^{6} \mathrm{u}^{\mathbf{6}} \overline{\mathrm{O}}^{6} \overline{\mathbf{o}}-\mathrm{Kupaianaha}$ flow field (1983-2007); green, Hawai'i Volcanoes National Park not covered by $P^{6} u^{6}{ }^{6} \bar{O}^{`} \overline{0}-$ Kupaianaha lava flows.

The resulting map characterizes how fluids, such as water and lava, would drain across the topography. If Puna could support streams and rivers, the drainage pattern might look like figure 1. The pattern of these flow paths is rather simple; the east rift zone forms a topographic divide, and flows starting north of the divide advance northeastward while flows starting south of the divide advance southeastward.

Of course, these calculations are only as good as the accuracy of the DEM. Lava flows are notorious for responding to very subtle local topographic variations, although they still respond predictably on a regional scale. The paths presented in figure 1 are reasonable approximations. These paths should, therefore, provide useful guides to where initial flows would travel, and they compare well with the paths of actual flows portrayed on the geologic map of Hawai' $i$ Island (fig. 2; Trusdell and others, 2006). 


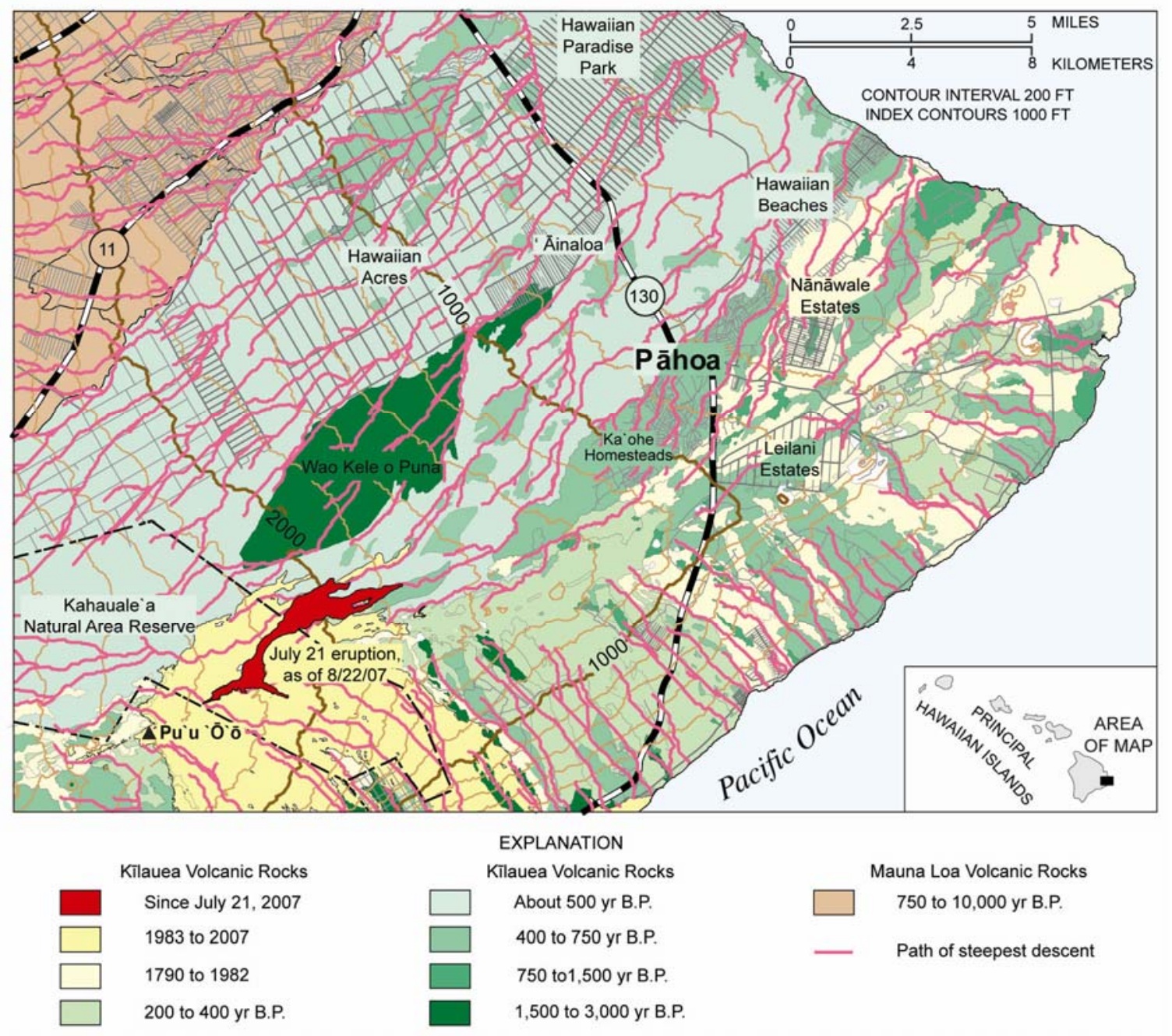

Figure 2. Calculated flow paths superimposed on geologic map of Island of Hawai'i.

Lava flows change the topography, so that subsequent flows will travel along new paths of steepest descent incorporating the new, lava-flow-included topography. Because this lava-included topography doesn't exist yet, it can't be included in any DEMs. Therefore the paths of steepest descent shown here are useful for estimating only the initial paths of lava flow advancement. Past tests of this method show that the forecast paths would have been very useful indicators for the direction followed by the Mauna Loa 1984 lava flow (Kauahikaua and others, 2003) and for the path of the 2002 Mother's Day flow on Kîlauea that sparked numerous forest fires. Figure 2 also shows that both the northernmost flows erupted from early $\mathrm{Pu}^{\prime} \mathrm{u}{ }^{\prime} \overline{\mathrm{O}}^{`} \overline{\mathrm{o}}$ and the $7 / 21$ lava flows to the northeast are following these paths.

\section{The current situation: the July 21 fissure eruption}

Events leading up to the July 21 fissure eruption began on June 17, 2007, when an earthquake swarm started beneath the Mauna Ulu area in the upper east rift zone of Kîlauea Volcano.

Earthquake hypocenters migrated first uprift and then downrift late on June 18-the classic signal of an intrusion. GPS receivers spanning the rift zone in this area began to show extension across the 
rift zone, also supporting this interpretation. By daylight on June 19, a very small eruption had taken place on the east flank of Kāne Nui o Hamo, the lava shield immediately north of Makaopuhi Crater.

Coincident with the intrusion and eruption, the crater floor in $\mathrm{Pu}^{\prime} \mathrm{u}{ }^{`} \overline{\mathrm{O}}^{`} \overline{\mathrm{o}}$ collapsed as much as 100 $\mathrm{m}$, and all signs of eruption-related activity stopped. Lava was absent until July 2, when a small amount was seen oozing from the crater floor rubble. Over the next 18 days, lava formed a perched lava pond within the crater. In addition to the lava fill, the entire interior of the crater, including the lava fill and the talus piles at the base of the crater walls, began to rise starting on or about July 10 , possibly indicating shallow pressurization of a magma reservoir beneath the crater.

Just after midnight on the morning of July 21, 2007, a 2.1-km-long set of fissures opened east of $\mathrm{Pu}^{6} \mathrm{u}^{\prime} \overline{\mathrm{O}}^{`} \overline{\mathrm{o}}$ crater coincident with another collapse of the crater floor. The fissure had four segments, labeled A, B, C, and D (fig. 3). Segment A became inactive within several hours while segments B, $\mathrm{C}$, and D built perched ponds and sent short flows southeastward. Within a few days, however, most of the activity was concentrated at fissure segment $\mathrm{D}$, the lowest and easternmost fissure.

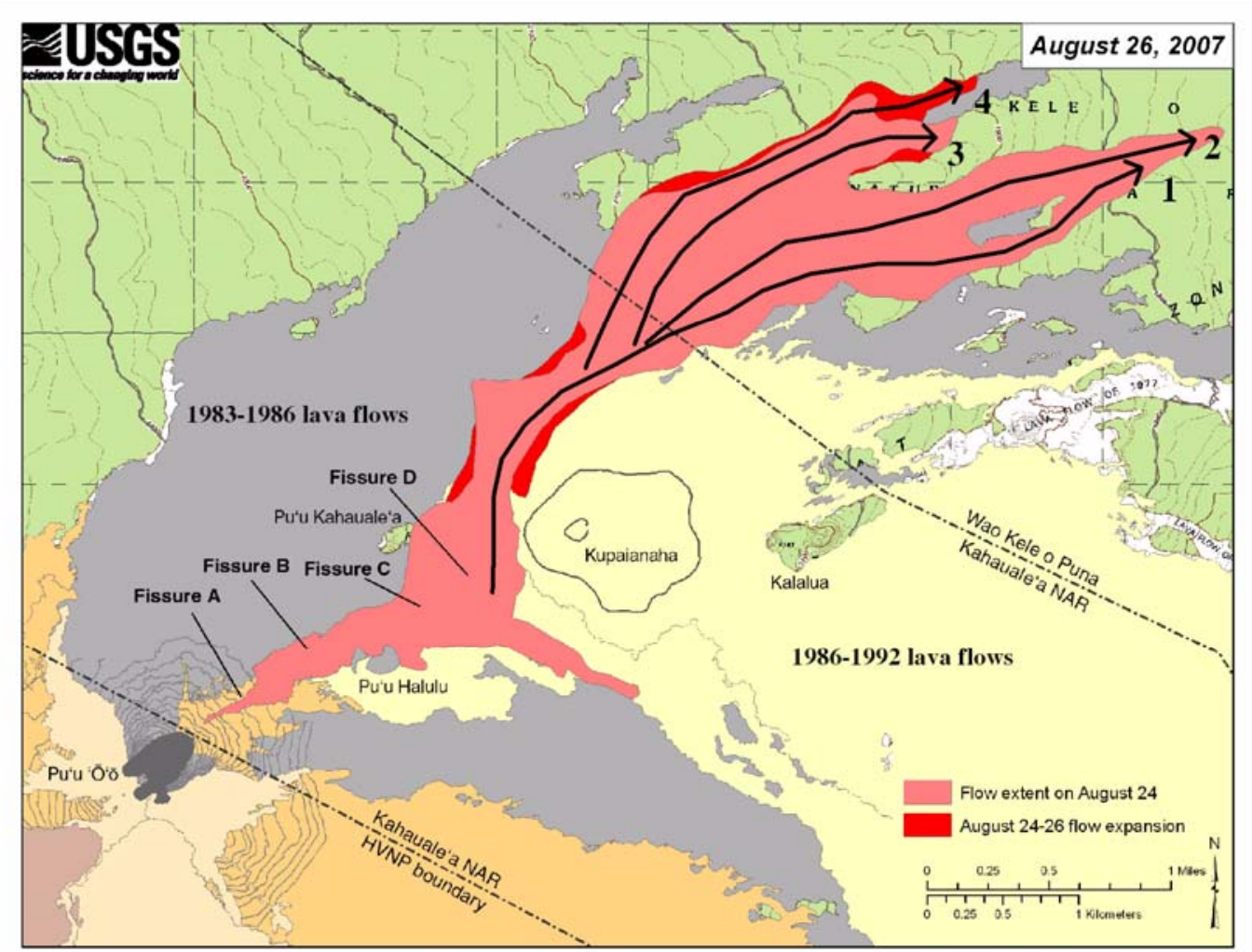

Figure 3. Lava flow map as of August 26, 2007. Black lines and arrowheads show the tracks of four 'a'ā flows that started from the fissure $D$ channel. Gray represents primarily ' $a$ ' $\bar{a}$ lava flows emplaced during the fountaining episodes of $\mathrm{Pu}^{6} \mathrm{u}{ }^{6} \overline{\mathrm{O}}^{\top} \overline{\mathbf{o}}$ (1983-1986); green represents forested areas not inundated by lava flows since 1977; yellow represents primarily pāhoehoe lava flows emplaced from 1986 to 1992.

By July 26, the northeast edge of the perched pond atop fissure D failed, and lava spilled out to form a channel feeding an ' $\mathrm{a}^{\prime} \overline{\mathrm{a}}$ flow. The first flow advanced $6.3 \mathrm{~km}$ before stalling by about August 13. The channel breached about halfway along the first flow and formed a second flow 
toward the north. By August 24, a second breach occurred, starting flow 3 (and starving flow 2 of lava), and followed by a third breach, starting flow 4 and starving flow 3 of lava. Thus, three ' $a$ ' $\bar{a}$ flows have stalled and a fourth is active at this writing on August 26 (fig. 3).

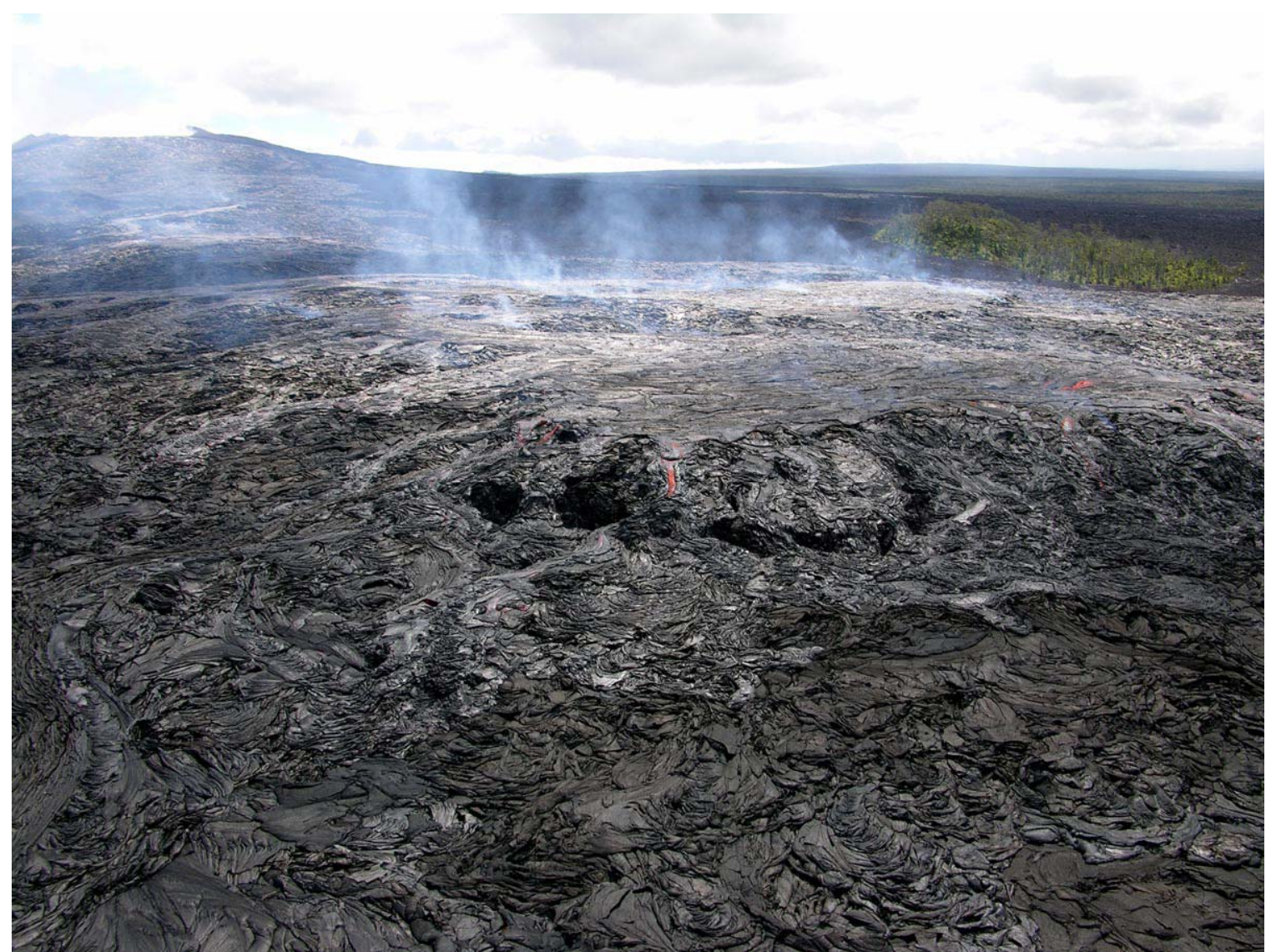

Figure 4. Looking back toward $P^{\prime}{ }^{\prime}{ }^{~}{ }^{\prime} \bar{O}^{`} \overline{0}$, a perched lava pond was forming over fissure $D$ in this July 23,2007 photo. Pu'u Kahauale'a is the vegetated cone behind the perched pond.

Because fissure D is now within the walls of the former perched pond that formed over it, all lava flows are directed north and northeast.

\section{What immediate hazards does the newest eruptive activity pose?}

Lava flows moving through forest can trigger methane explosions and forest fires. Methane explosions are hazards local to the flow front and margins of an advancing lava flow. The explosions can propel rock and molten lava up to one hundred meters (300 feet) into the air. The threat of forest fires ignited by lava flows is highest whenever dry vegetation is encountered. Therefore changes in the fire threat are dependent mostly on changes in meteorology and/or vegetation type.

Beyond these hazards, the current episode poses no direct and immediate lava flow threat to nearby communities as long as eruptive conditions do not change. 


\section{What future hazards might the newest eruptive activity pose?}

There are three possible outcomes to the current activity. Each has different hazard implications.

\section{The $7 / 21$ fissure activity stops}

The eruptive activity could revert to $\mathrm{Pu}^{\prime} \mathrm{u}{ }^{\prime} \mathrm{O}^{‘} \overline{\mathrm{o}}$ and continue in much the same manner as it has for the last few years. If the eruption stops altogether, the longer the lack of activity persists, the greater the probability that the next Kilauea eruption will be elsewhere on the volcano. These become the same probabilities and the same hazards addressed in the long-term hazard outlook.

\section{The $7 / 21$ fissure activity continues to feed a channel that spawns 'a'ā lava flows}

If the eruption continues to supply lava at the same rate to an open channel feeding 'a' $\bar{a}$ lava flows, then individual flows will rarely advance more than a few kilometers (miles) from the fissure. This is primarily because so much heat is lost from the open channel (Cashman and others, 1999) that the lava viscosity increases to the point that the flow can no longer advance. Once the terminal length is achieved, the flow front stalls and lava overflows the channel behind the front to start another ' $a$ 'ā flow.

The lengths of channel-fed ' $a$ ' $\bar{a}$ flows are controlled by the effusion rate feeding them (Pinkerton and Wilson, 1994). Higher effusion rates allow lava to travel farther from the vent. Thus, if the effusion rate from the 7/21 fissure were to increase significantly, the length of the resulting channel-fed ' $a$ 'a flows would likewise increase. Of course, if the eruption rate were to decrease yet maintain an open channel, 'a'a flows fed by that channel would not advance as far or would stall.

As of August 26, the 7/21 fissure eruption has produced four ' $a$ 'a $\mathrm{a}$ flows, each advancing along the northern edge of the previous flow with a maximum length of $6.3 \mathrm{~km}$ (4 miles). Without a significant increase in effusion rate, 'a'a flows from this vent are unlikely to travel substantially farther than this distance.

Changes at the vent could potentially allow lava to flow southeastward. The flows are currently advancing north and northeastward around Kupaianaha. Should the erupting lava spill over the low walls to the south of fissure D, flows could also advance to the southeast.

\section{The 7/21 fissure channel crusts over and spawns pāhoehoe lava flows and lava tubes}

If the now-open lava channel crusts over and forms a lava tube, the new structure will better insulate the molten lava erupting from fissure D and allow it to remain hotter farther down its path. Because of the improved insulation, the hotter lava will promote the formation of pāhoehoe flows. The combination of pāhoehoe flows and lava tubes that feed them can allow lava to flow farther from the vent, for a given effusion rate, than the ' $a$ 'a flows that are currently erupting.

Pāhoehoe lava flows often advance sporadically, with tubes rupturing and forming new flows and tubes within those flows. Regardless, the flows progress downslope. Flows from Kupaianaha, 
which started on July 20,1986, from a fissure in the same area, reached the ocean to the southeast in 4.5 months. The advance seaward was neither as a single lava flow nor at a constant rate. If pāhoehoe flows spread northeast from fissure $\mathrm{D}$, they will likely advance at a slower rate those from Kupaianaha did, because the average slopes north of the rift zone are much less steep.

As in the previous scenario with ' $a$ 'a flows, substantial changes in the configuration of the vent could allow flows to advance southeastward. In any case, the flow paths calculated for the Puna District (fig. 1) will be useful to forecast paths on which lava flows will advance in any direction. The greatest utility of these maps is not as a future lava flow roadmap but as a guide for the way lava flows will advance over distances of a few kilometers (miles). Uncertainties in the DEMs used to calculate these paths and complexities of lava flow mechanics are the limiting factors.

While not the current one, this scenario becomes more probable the longer the current eruptive activity continues. Kỉlauea Volcano has never had a long-lived continuous eruption from a single vent that produced only ' $a$ 'ā flows. Relevant eruption examples from Kīlauea are the 1840 east rift zone eruption ( 21 days of ' $a$ ' $\bar{a}$ from the lowest vent); the 1919 Mauna Iki southwest rift zone eruption (221 days of mostly pāhoehoe; Rowland and Munro, 1993); the 1955 east rift zone eruption ( 88 days of ' $a$ ' $a$ from multiple vents); the 1960 east rift zone eruption (36 days of fountains and ' $a$ 'a flows from one vent); the 1969-1971 and 1972-1974 Mauna Ulu eruptions (predominantly pāhoehoe after fountaining ceased); and the 1977 east rift zone eruption (18 days of ' $a$ 'ā from one vent; Moore and others, 1980).

\section{Conclusions as of August 26, 2007}

Lava flows from the 7/21 fissure eruption pose no direct immediate threats to communities. However, possible future outcomes of the current activity outlined above warrant increased public awareness and enhanced monitoring. It is important to realize that the current activity and all of the future outcomes are consistent with the long-term lava flow hazard outlook for the Puna district provided in Wright and others (1992).

\section{Acknowledgments}

The events of the last several months have been recorded in detail by a number of current and former HVO staff members - Tim Orr, Frank Trusdell, Don Swanson, Mike Poland, Jeff Sutton, Tamar Elias, Asta Miklius, Dave Wilson, Christina Heliker, and Rick Hoblitt. This report has benefited greatly from discussions with HVO staff and excellent reviews by Tim Orr, Frank Trusdell, Don Swanson, Rick Hoblitt, and two colleagues from the University of Hawai ${ }^{i} \mathrm{i}-\mathrm{Scott}$ Rowland and Ken Hon. A special mahalo goes to Dave Sherrod, who not only reviewed the manuscript and offered very helpful suggestions but also greatly improved the presentation of the two maps.

\section{References cited}

Cashman, K.V., Thornber, C., and Kauahikaua, J., 1999, Cooling and crystallization of lava in open channels, and the transition of pāhoehoe lava to 'a'â: Bulletin of Volcanology, v. 61, p. 306-323. 
Clague, D.A., Hagstrum, J.T., Champion, D.E., and Beeson, M.H., 1999, Kīlauea summit overflows; their ages and distribution in the Puna District, Hawai'i:Bulletin of Volcanology, v. 61, p. 363-381.

Hawai'i State Civil Defense, 2002, Lava flow hazard mitigation plan; Reducing the risk of lava flows to life and property: $75 \mathrm{p}$.

Kauahikaua, J., Sherrod, D.R., Cashman, J.V., Heliker, C., Hon, K., Mattox, T.N., and Johnson, J.A., 2003, Hawaiian lava-flow dynamics during the $\mathrm{Pu}^{\prime} \mathrm{u}$ ' $\mathrm{O}^{`} \overline{\mathrm{o}}-\mathrm{Kupaianaha}$ eruption; a tale of two decades: U.S. Geological Survey Professional Paper 166, p. 63-87 [Available free online at http://geopubs.wr.usgs.gov/prof-paper/pp1676/pp1676_04.pdf.]

Moore, R.B., Helz, R.T., Dzurisin, D., Eaton, G.P., Koyanagi, R.Y., Lipman, P.W., Lockwood, J.P., and Puniwai, G.S., 1980, The 1977 eruption of Kilauea Volcano, Hawaii; Journal of Volcanology and Geothermal Research, v. 7, p. 189-210.

Pinkerton, H., and Wilson, L., 1994, Factors controlling the lengths of channel-fed lava flows:Bulletin of Volcanology, v. 56, p. 108-120.

Rowland, S.K., and Munro, D.C., 1993, The 1919-1920 eruption of Mauna Iki, Kilauea; chronology, geologic mapping, and magma transport mechanisms: Bulletin of Volcanology, v. 55, p. 190-203.

Trusdell, F., Wolfe, E.W., and Jorris, J., 2006, Digital database of the geologic map of the Island of Hawai'i: U.S. Geological Survey Digital Data Series DS-144. [Available free online at http://pubs.usgs.gov/ds/2005/144/.]

Wright, T.L., Chun, J.Y.F., Espose, J., Heliker, C., Hodge, J., Lockwood, J.P., and Vogt, S., 1992, Map showing lava flow hazard zones, Island of Hawaii: U.S. Geological Survey Miscellaneous Field Studies Map MF-2193, scale 1:250,000. 